\title{
ROLE OF BACILLUS THURINGIENSIS ISOLATE AS BIOLOGICAL CONTROL AGENT AGAINST WHITEFLY, BEMISIA TABACI (GENN.) AND THE SIDE EFFECT ON THE PREDATOR, EUSEIUS SCUTALIS
}

\author{
Iman I. Imam ${ }^{(1)}$ and M. A. Nawar ${ }^{(2)}$ \\ ${ }^{(1)}$ Economic Entomology Unit, Plant Protection Department, Desert Research Center. \\ (2) Animal Pest Unit, Plant Protection Department, Desert Research Center.
}

Received: Nov. 26, 2019

Accepted: Dec. 26, 2019

\begin{abstract}
The potential of a certain Bacillus thuringiensis isolate against firstinstar nymphs and newly emerged adults (i.e., sucking stages) of Bemisia tabaci, could be detected on the basis of the calculated $L C_{50}$ values which recorded 17.7and18.21CFU/mI respectively, This means that, The effect of the bioinsecticide was stronger on adult individuals. On the other hand the calculated $L C_{50}$ values on newly emerged adults of Euseius scutalis by indirect and direct exposure were 4.89 and 27.5 $\mathrm{CFU} / \mathrm{ml}$ respectively; this means that indirect exposure was more effective than direct exposure. Biological control agents should be directed to reduce the pest and preserve the predator (natural enemy).
\end{abstract}

Key words: Bacillus thuringiensis, Bemisia tabaci, Euseius scutalis, bioinsecticides.

\section{INTRODUCTION}

Sweet potato whitefly, Bemisia tabaci, Genn, is a polyphagous and multivoltine insect pest responsible for high economic losses in many crops with great economic impacts on many crops such as cotton, vegetables, fruit crops and ornamentals, (Khanjani, 2007 \&Omid Bakhsh et al., 2010). Whiteflies damage plants directly by sucking plant sap causing the silvering of leaves, irregular colour of fruits and growth stunting especially in young plants, and indirectly, whiteflies transmit several plant viruses (Lapidot and Polston, 2006). B. tabaci transmits plant viruses in seven distinct groups including: potyviruses, geminiviruses, carlaviruses, closteroviruses, nepoviruses, luteoviruses and DNA-containing rodshaped virus (Thompson, 2011). Also, they excrete honeydew which stimulate the growth of sooty mold hindering the photosynthesis process (Byrne and Bellows, 1991).
Euseius scutalis (A-H), is a common phytoseiid mites in Egypt. Predatory mites of the family Phytoseiidae are of economic importance because they are efficient bio-agents that can be used against insect and mite pests in many crops in the open fields and in the greenhouses worldwide (Fouly et al. 2013).

Many phytoseiid species are facultative predators (generalists), not only on spider mites but also on other sources of food such as whiteflies, pollen (Fouly and Hassan 1991; Gnanvossous et al., 2005; and Al-Shammery, 2011), and thrips(van Houten et al., 2005; Messelink et al., 2005; and Winner et al., 2008). The two phytoseiid mites Neoseiulus cucumeris (Oud.) and Neoseiulus barkeri (Hughes) are known to play a natural important role in controlling the spider mites of the family Tetranychidae and Eriophyidae as well as the whiteflies and thrips on vegetables (Fouly et al., 2011). 
Alternative methods for insect control could provide acceptable levels of pest control with lower hazards. One of these alternatives is the use of bioinsecticides that contain microorganisms have valued importance because their toxicity to animals and human is verylowCompared to insecticides, (Al Arabiat et al., 2018 and Al-Momany and Al-Antary, 2008),. Themost widely used in the world are preparations of Bacillus thuringiensis (B.t.) (Federici, B.A. 1999),. The insecticidal activity of (B.t.) is due to containing parasporal inclusions produced during sporulation. Bioinsecticides based on the proteinaceous-endotoxin of (B.t.) constitute part of a more ecologically rational pest control strategy (Mehrabi, et al., 2018), B. thuringiensis infects Lepidoptera, Diptera, Coleoptera, Hymenoptera, Hemiptera, Phthiraptera, Orthoptera, and Mallophaga. (Federici, 1999, and Al Arabiat et al., 2018).

This study conducted to evaluate the direct effect of certain Bacillus thuringiensis isolate on Bemisiatabaci and its predator Euseius scutalis; as well as the indirect effect on the predator fed on treated whitefly.

\section{MATERIALS AND METHODS}

Mites and insects collection:

Phytoseiid mite species, Euseius scutalis (Athias-Henriot) and Bemisia tabaci were collected from leaves and twigs of castor plants, Ricinus commuunis.

\section{Rearing of Euseius scutalis:}

Euseius scutalis reared on leaf discs of castor plants Ricinus commuunis one square inch each was used for rearing predator during its whole the test. Adult were singly transferred from the culture to the aforementioned leaf discs which were kept on a moist cotton pad in Petri dishes (15 cm in diameter). (Foulyet al., 2013).

\section{Rearing of Bemisia tabaci:}

The whitefly strain was transferred to the laboratory and reared on seedlings of castor planted in small pots $25 \mathrm{~cm}$ (diameter) and kept under plastic greenhouse conditions of $27 \pm 2{ }^{\circ} \mathrm{C}, 70 \pm 5$ $\mathrm{RH}$, and photoperiod 14:10 (light: dark). The plant pots were carried to cages $(60 \times 60 \times 120 \mathrm{~cm})$. Lateral sides of the cages were covered by thin gauze $(10 \times 10)$ mesh led to suitable ventilation. Whitefly cultures were established by transferring 50-60 adults to each cage. The insects were screened on the upper surface of the plants using circular clips cages $(2 \mathrm{~cm}$ in diameter, 3.14 surface area) for 72 hours.

\section{B.t. Isolation Technique:}

Soil samples were collected randomly from different fields in El-Bahariya Oases., Surface materials of the soil was removed; and with a sterile spatula, about $100 \mathrm{gm}$ sample of soil was taken from at least $5 \mathrm{~cm}$ in depth. The soil samples were preserved in sterile plastic bags and stored for $2-12$ months at $4^{\circ} \mathrm{C}$ until analyzed. The collection sites had no history of treatment with B.t.

Based on the acetate selective method described by (Smithand Couche 1991), soil samples $(0.5 \mathrm{~g})$ were added, each to $10 \mathrm{ml}$ of LB broth buffered medium with $0.25 \mathrm{M}$ sodium acetate buffer at $\mathrm{pH} 6.8$ in a sterile conical flask under aseptic conditions in a laminar flow workstation. The flask was incubated in a controlled environment incubator shaker, Edmund Bühler (TH25) operated at $300 \mathrm{rpm}$ and $30^{\circ} \mathrm{C}$ for four hours. In this method, germination of B.t. spores was selectively inhibited by sodium acetate buffer $(0.25 \mathrm{M})$, while most of the 
undesired spore-formers germinated. Then suspensions were allowed to stand for 10 minutes; the upper layer of suspended samples were transferred to a sterile test tube with screw cap followed by heat treatment at $80^{\circ} \mathrm{C}$ for three minutes in a water bath. Heat treatment was made to eliminate all vegetative cells and non-sporulated soil microorganisms present in the samples. The samples were left to cool at room temperature before inoculating $1 \mathrm{ml}$ of the supernatant using sterile pipettes onto agar plates and distributed over agar surface homogeneously. The plates were incubated overnight at $30^{\circ} \mathrm{C}$; then random colonies of B.t. from agar plates were transferred onto T3 - plates using sterile loop. Transferred colonies were left for 2-3 days at least to allow complete sporulation and crystal formation characteristic for B.t. isolate. Careful aseptic techniques were done for investigating the germinated colonies using a laminar flow workstation. Examination of germinated colonies was done using stained smears method. The germinated colonies were fixed to clean slides and stained according to (Smirnoff 1962) stain method. For culturing the obtained isolates, the method Shake Flask Fermentation described by (Morris et al., 1996), Small quantities of B.t. can easily be recovered by the lactoseacetone co-precipitation procedure of (Dulmage et al., 1970), determine the number of bacteria that are present in the isolates described by (Dulmage 1971), the total number of bacteria in the original solution was determined by counting the number of colony forming units (CFU's) and comparing them to the dilution factor.After that serial dilutions from the original bacterial suspension were obtained. Tube 1 contains $4.5 \mathrm{ml}$ of water; in addition to $0.5 \mathrm{ml}$ of the undiluted bacterial suspension to yield a total volume of $5.0 \mathrm{ml}$.

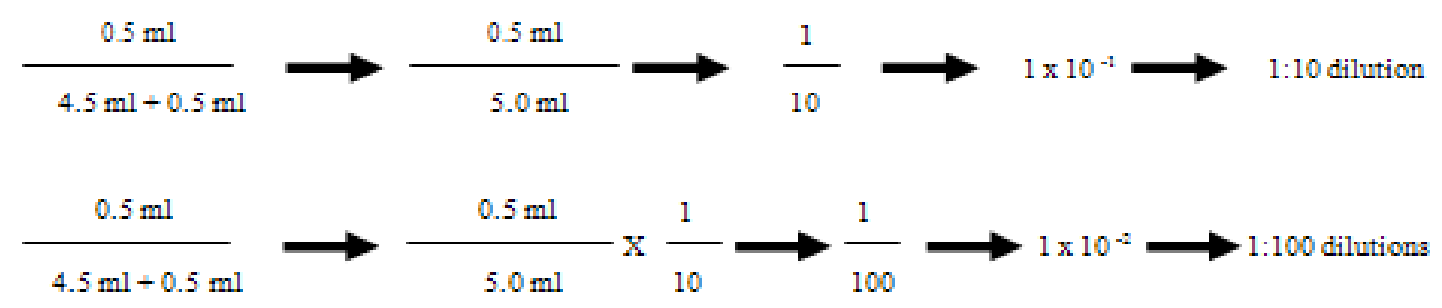

For each dilution, the number of colony forming units (CFU) on the plates was counted. Typically, numbers between 30 and 800 are considered to be in the range of statistically accurate data. To calculate the number of bacteria per $\mathrm{ml}$ of diluted sample, the following equation was used:

$\frac{\text { Number of CFU }}{\text { Volume plated (m) } x \text { total dillution used }} \rightarrow \frac{\text { Number of CFU }}{\mathrm{ml}}$

\section{Toxicity Test:}

\section{Application on whitefly:}

The leaf dipping technique was used (Yang et al., 2010). Plant leaves were dipped in four concentrations of the tested isolate $(1.25,2.5,5$, and 10 $\mathrm{CFU} / \mathrm{ml}$ ), control leaves were dipped in water. After drying at room temperature, 10 starved $2 \mathrm{~d}$ - old first- instar nymphs and newly emerged adults (male and female) (i.e., sucking stages) of B. tabaci, was placed on the treated leaf, Mortalities were recorded after 12, 24, and 48 hours. Each experiment had 5 replications. 
Method of application on phytoseiid mite:

\section{1- Direct effect:}

The residual film technique was used. $3 \mathrm{ml}$ of the desired concentration were evenly spread on a Petri dish surface (9 $\mathrm{cm}$ in diameter). The solvent allowed being evaporated leaving a film of several concentration of bacterial isolate (1.25, $2.5,5,10 \mathrm{CFU} / \mathrm{ml}$ ), Pair of newly emerged adults (male and female) of $E$. scutalis were exposed to the thin film for $\mathbf{2 4}$ hour, and feeding on appropriate quantity of untreated Bemisiatabaci, (Farag, 1986). The control specimens were treated with water, each concentration was replicated 5 times.Inspection was carried outdaily and Mortalities were recorded after 12, 24, and 48 hours.

\section{2- Indirect effect:}

Newly emerged adults (male and female) of $E$. scutalis were fed on whitefly previously treated with sublethal concentrations of bacterial isolate, (1.25, 2.5, 5, $10 \mathrm{CFU} / \mathrm{ml}$ ) (Baoying et al., 2001), the control specimens were treated with water. Mortality percentages of the predator were recorded.

\section{Statistical analyses}

Data obtained in different tests were subjected to statistical analysis to evaluate the relative efficiency of the isolates. Mortalities were corrected for the natural mortality according to (Abbot's formula 1925).

Concentration / mortality regression lines were drawn on probit logarithmic graph according to the method developed by (Finney 1971).

The $L C_{50}$ and $L_{90}$ values were calculated according to probane program.

\section{RESULTS AND DISCUSSION Toxicity Test:}

As shown in chart (1) the effect of tested concentrations of $B$. thuringiensis isolate on 2 day old first- instar nymphs of $B$. tabaci, could be detected on the basis of the calculated $\mathrm{LC}_{50}$ and $\mathrm{LC}_{90}$ values which recorded 17.7 and 41.84 $\mathrm{CFU} / \mathrm{ml}$ respectively, slope of the concentration-mortality line was 3.4174 . While In case of $B$. tabaci adults LC $_{50}$ and $L C_{90}$ values was recorded as 18.21 and 43.36 $\mathrm{CFU} / \mathrm{ml}$ respectively, where, its slope line recorded 3.40 . The various concentration of B.t. isolate was more toxic for nymph stages than adult one Chart (2).

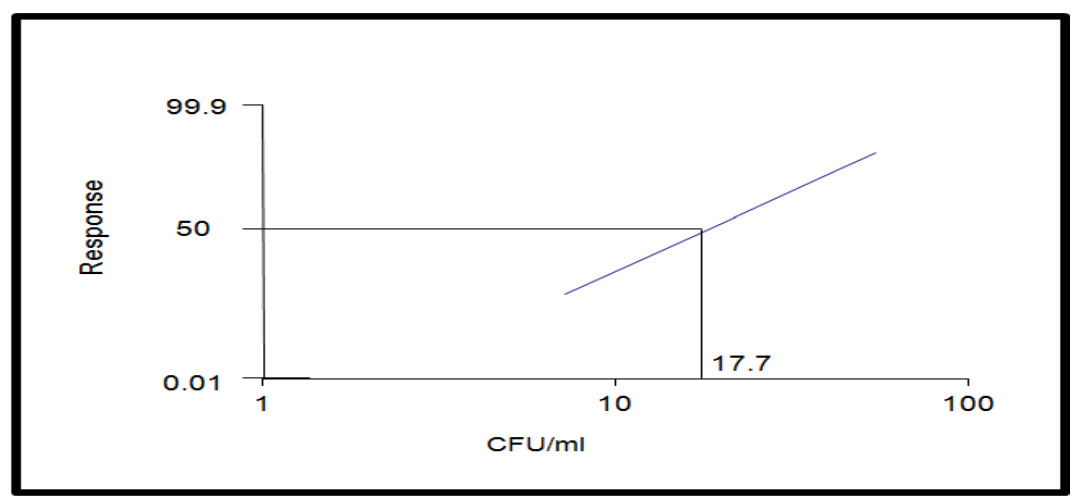

Chart (1): Concentration / mortality regression lines for B. tabaci nymphs treated with tested concentrations of $B$. $t$. isolate. 


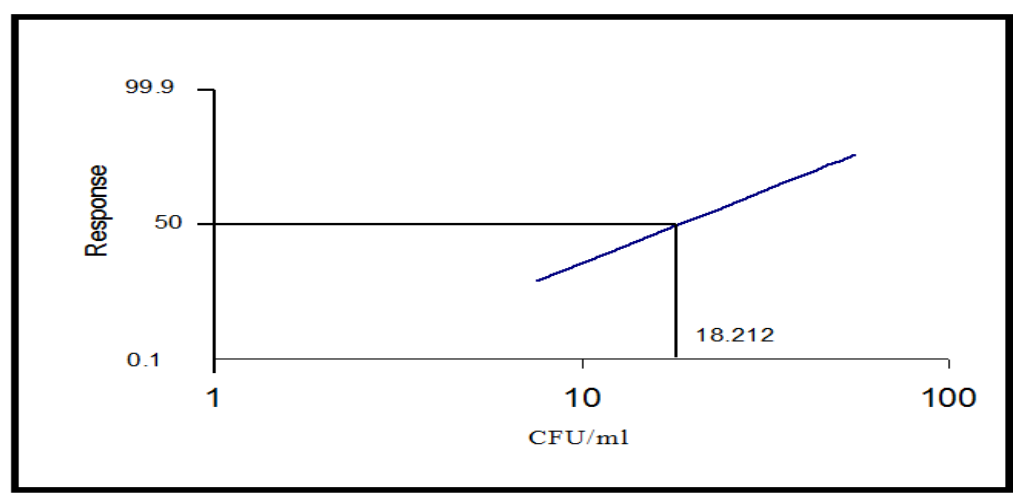

Chart (2): Concentration / mortality regression lines for B. tabaci adults treated with tested concentrations of $B$. $t$. isolate.

The obtained date in this study on the effectof $B$. $t$. isolate on 2 day old firstinstar nymphs of $B$. tabaci, are in agreement with those reported by (Radwan et al., 1984). A possible explanation for the mortality rates found could be the contact action of the tested isolate concentration. (Wilkinson and Ignoffo 1975) suggest the usefulness of B.t. preparation as a control measure to reduce the whitefly population. The genus Bacillus e.g. $B$. pumilus, $B$. pasteurii, $B$. thuringiensisand $B$. Subtilis which are often utilized as a bio-control agent (Al Arabiat et al., 2018 and Kloepper et al., 2014), These bacteria can promote growth and provideplant protection by antibiosis and/or ISR elicitationin many crops. For example reduced insect herbivoresin cucumber (Zehnder et al., 1997 and Al-Momany and Al-Antary, 2008), however ISR cause dreduction of $P$. syringae and $p v$. Tabaci in the field and greenhouse (Park and Kloepper, 2000) and Peronospora tabacina (Zhang et al., 2002).

The indirect tested concentrations of $B$. $t$. isolate on newly emerged adults of E. scutalis could be detected on the basis of the calculated $L^{2} C_{50}$ and $L C_{90}$ values which recorded 4.89 and 289.68 , CFU $/ \mathrm{ml}$ respectively, slope of the concentrationmortality line was 0.7276 .(Chart3), While the calculated $L C_{50}$ and $L C_{90}$ values by direct exposure (chart 4), recorded 27.5 and 107.546. CFU/ml respectively, and its slope line was 2.18. This means that indirect exposure was more effective than direct exposure.

Field applications of thuringiensin were successful against the citrus red mite P.citri (Hall, et.al., 1971) and Tetranychus pacificus (Hoy and Ouyang, 1987). Later, (Royalty et al.,1990) conducted experiments by testing two different formulations of thuringiensin against the two spotted spider mite $T$. urticae. The results indicated that thuringiensin might be a potential acaricide. In particularyounginstars are susceptible, since these have a high growth rate. Various physiological processes in young organisms require higher RNA synthesis than inthe older slower growing stages. A major drawback is that thuringiensin is toxic fora wide range of organisms. Not only are spider mites affected, but also beneficialmites, such as Phytoseiulus persimilis.The chemical is apparently a nonselectiveacaricide that should not be used in combination with predatory mites.The spore-crystal complex of $B$. thuringiensis has been tested on spider mitesby (Krieg, 1972), but no mortality was observed. However, (Chapman and Hoy, 1991), conducted experiments in which T. urticae and 
Metaseiulusoccidentalis were treated with a commercial preparation of $B$. thuringiensis var. tenebrionis. Thisvariety of $B$. thuringiensis shows an effect on beetles and is recommended for useagainst the Colorado potato beetle, Leptinotarsadecemlineata. No effect was notedon the twospotted spider mite, this toxic effect could be enhanced by starving the mites: theauthors assumed that starvation may lead to a higher uptake of the material, or thatthe mites were more exposed to the preparation as starving mites tend to movefaster. It is also possible that starvation acts as a stress factor. The authors have noexplanation for the toxic effect on the predatory mite: the preparation did not containthe $\beta$-exotoxin (thuringiensin) known to be toxic for mites.In more recent years, isolates of $B$. thuringiensis have been found that do showtoxicity towards spider mites and house dust mites (Payne, et al., 1993 and 1994). It has been suggested to isolate the $\delta$ endotoxin of theseisolates and to formulate it as an acaricide. One may also transfer the gene, encoding forthis specific $\delta$-endotoxin into a crop plant in order to protect the crop against spider miteinfestations.Aninterestingdiscovery is the isolation of a $B$. thuringiensis strain from dead two spotted spider mites, T. urticae (Jung et al., 2007).The results of this study were identical to (ElBanna et al., 2002), showed thatthe indirect exposure technique of both Neem Azal formulation and organophosphorus insecticide [Actellic compound] on Aphis craccivora Kock and its predator Coccinellaundecimpunctata is more effective than the direct exposure technique.

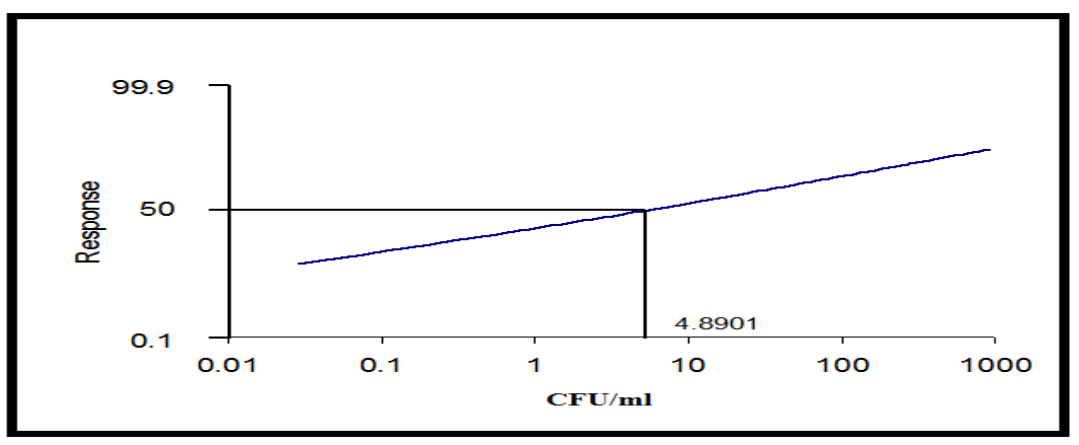

Chart (3): Concentration / mortality regression lines for E. scutalis adult indirect treated with tested concentrations of $B$. $t$. isolate.

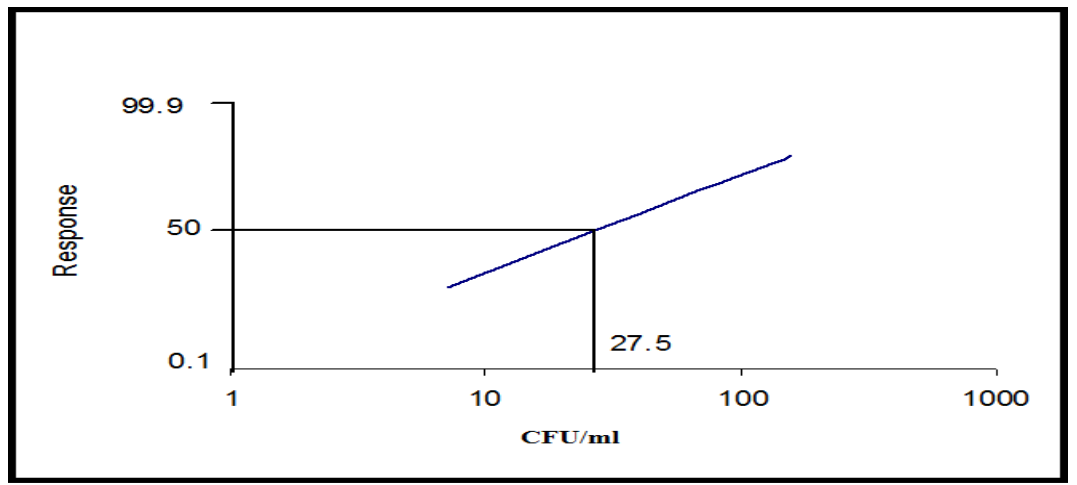

Chart (4): Concentration / mortality regression lines for E. scutalis adult direct treated with tested concentrations of $B$. $t$. isolate 


\section{REFERENCES}

Abbott, W. S. (1925). A method of computing the effectiveness of an insecticide. Jour. Econ. Entomol., 18: 265.

Al Arabiat, O.W., S.A. Araj, K.M. Alananbeh and T.M. Al-Antary (2018). Effect of three Bacillus spp. on tobacco whitefly Bemisiatabaci (Gennadius) (Homoptera: Aleyrodidae). Fresen. Environ. Bull. 27, 3706-3712.

Al-Momany, A. and T.M. Al-Antary (2008). Pests of Garden and Home. Second edition. Publications of University of Jordan, Amman.518 p.

Al-Shammery, K. A. (2011). Plant pollen as an alternative food source for rearing Euseiusscutalis (Acari:

Phytoseiidae). Jour. Entomol. 8(4):365-374.

Baoying, Q., G. Gordh and G. Walter (2001). Effects of Neem F Prey on the Predacious Insects Harmoniaconformis (Boisduval) (Coleoptera: Coccinellidae) and Malladasignatus (Schneider) (Neuroptera) Biological Control, 22, [October], 1.

Byrne, D.N., Bellows T.S. Jr. (1991). Whitefly biology. Ann. Rev. Entomol., 36: 431-457.

Chapman, M. H. and M. A. Hoy (1991). Relative toxicity of Bacillus thuringiensis var. tenebrionis to the two-spotted spider mite (Tetranychusurticae Koch) and its predator Metaseiulusoccidentalis (Nesbitt) (Acari, Tetranychidae and Phytoseiidae). Journal of Applied Entomology, 11: 147-154.

Dulmage, H. T. (1971). Insecticidal activity of $\mathrm{HD}-1$, a new isolate of Bacillus thuringiensis var. alesti. Jour. Invertebr. Pathol., 15: 232-239.

Dulmage, H. T., J. A. Correa and A. J.Martinez (1970). Co- precipitation with lactose as means of recovering the spore- crystal complex of Bacillus thuringiensis, Jour. Invertebr. Pathol., 18: 353-360.

El-Banna A. A.; G. A. Abdel-Rahman and Iman I. Imam (2002): Toxicity of Nemazal-F to Coccinellaunde cimpunctata L. (Coleoptrae Cocciniledae), and the related biological effect. Jour. Egypt. Acad. Soc. Environ. Develop. (AEntomology) 2 (2): 67 -81.

Farag, A. N. (1986). Effect of some new compounds used for pest control on the biology and physiology of certain natural enemies of cotton pests. Ph.D. Thesis Fac. Agric., Cairo University.

Federici, B.A. (1999). Bacillus thuringiensis in biological control. Handbook of Biological control. Academic Press, San Diego, 575-593.

Finney, D.J. (1971). Probit Analysis. Cambridge Univ. Press. 333 pp.

Fouly, A.H. and M.F. Hassan (1991). Effect of crowding and food level on the predaceous phytoseiid mite Amblyseiusgossipi (El-Badry) fed on white fly Bemisiatabaci (Gennadius). Bull. Zool. Soc. Egypt. 40:141-146.

Fouly, A.H., M.A. Al-Daghairi and N.F. Abdel Baky (2011). Effect of crowding and food level on the biology of Typhlodromipsswirskii (Acari: Gamasida: Phytoseiidae) fed on whitefly Bemisiatabaci(Homoptera: Aleyrodidae). Jour. Entomol. 8(1):5262.

Fouly, A.H., O.A. Nassar and M.A. Osman (2013). Biology and life tables of Euseiusscutalis (A.-H.) reared on different kinds of food. Jour. Entomol. 10(4):199-206.

Gnanvossous, D., J.S. Yaninek and M. Toko (2005). Comparative life history 
traits of three neotropical phytoseiid mites maintained on plant-based diets. Biol. Control 35: 32-39.

Hall, I. M., D. K. Hunterand K. Y. Arakawa (1971). The effect of the b-exotoxin fraction of Bacillus thuringiensis on citrus red mite. Journal of Invertebrate Pathology, 18, 359-362.

Hoy, M. A. and Y. L. Ouyang (1987). Toxicity of b-exotoxin of Bacillus thuringiensis

Tetranychuspacificus to Metaseiulusoccidentalis (Acari: Tetranychidae and Phytoseiidae). Journal of Economic Entomology, 80, 507-511.

Jung, Y.-C., E. Mizuki, T. Akao and J. C. Côté (2007). Isolation and characterization of a novel Bacillus thuringiensis strain expressing a novel crystal protein with cytocidal activity against human cancer cells. Journal of Applied Microbiology, 103, 65-79.

Khanjani, M. (2007). Vegetable pests in Iran. Third Edition. Bu-Ali Sina University Press;. p. 465. In Persian.

Kloepper, W., M. Ryu and S. Zhang (2014). Induced systemic resistance and promotion of plant growth by Bacillus spp. Phytopathology. 94(11): 1259-1266.

Krieg, A. (1972). Über die Wirkung von Bacillus thuringiensis-Präparaten auf Spinnmilbe (Tetranychidae). AnzeigerfürSchädlingskunde, Pflanzenschutz, Umweltschutz, 45, 169-171.

Lapidot, M. and J.E. Polston (2006). Resistance to tomato yellow leaf curl virus in tomato, pp. 503-540. In (eds.) Loebenstein, G. \&Carr, J. P. Natural Resistance Mechanisms of Plants to Viruses, Springer Verlag, New York.

Mehrabi, M. R., L. Zoghlmofrad, M. Mazinani, A. Akbarzadeh and A. Rahimi (2018). A study of the effect of Bacillus thuringiensis serotype H14 (subspecies israelensis) delta endotoxin on Musca larva. Turkish Journal of Medical Sciences. 45, 794799.

Messelink, G., S.van Steenpaal and W.van Wensveen (2005). Typhlodromipsswirskii (Athias -Henriot) (Acari: Phytoseiidae): a new predator for thrips control in greenhouse cucumber. IOBC/wprs Bulletin 28(1): 183-186.

Morris, O. N., M. Trottier, V. Converse and P. Kanagaratnam (1996). Toxicity of Bacillus thuringiensis subsp. aizawai for Mamestraconfigurata (Lepidoptera: Noctuidae). Jour. Econ. Entomol., 89 (2): 359-365.

Omid Bakhsh M., G.R. Jemsi and F. Kocheili (2010). Effect of common pesticides on sweet potato whitefly Bemisiatabaci (Hem. Aleyrodidae) in fall cucumber at Ahwaz. Plant Prot. Jour., 2: 1-11.

Park, K.S. and J.W. Kloepper (2000). Activation of PR-1a promoter by rhizobacteria that induce systemic resistance in tobacco against Pseudomonas syringaepv. tabaci. Biological Control. 18(1): 2-9.

Payne, J., R. J. C. Cannon and A. L. Ralph (1994). Bacillus thuringiensis isolates for controlling acarides(20pp). US Patent 5,350,576.

Payne, J., R. J. C. Cannon and A. L. Bagley (1993). Bacillus thuringiensis isolates for controllingacarides (8pp). US Patent 5,211,946.

Radwan, H.S.A., A.A. Eissa, H.I.H. Omar and E.A.M. Moftah (1984). Latent effects of certain Bacillus thuringiensis preparations on the biology of the cotton whitefly, Bemisiatabaci. Minufiya Journal of Agricultural Research 8:417 - 429.

Royalty, R. N., F. R. Hall and R. J. Taylor (1990). Effects of thuringiensin on Tetranychusurticae

(Acari:Tetranychidae) mortality, 
fecundity, and feeding. Journal of Economic Entomology, 83, 792-798.

Smirnoff, W. A. (1962). A staining method for differentiating spores, crystals and cells of Bacillus thuringiensis Berliner. Jour. Invertebr. Pathol., 4: 384-385.

Smith, R. A. and G. A. Couche (1991). The phylloplanc as a source of Bacillus thuringiensis variants. Applied and Environmental Microbiology, 57: 311-315.

Thompson, W.M.O. (2011). The whitefly, Bemisiatabaci (Homoptera: Aleyrodidae) Interaction with Gemnivirus-infected host plants. Springwe, Netherland: 77-78. Thripstabaci in leek and onion crops. IOBC Bull. 22 (5): 61-72.

Van Houten, Y.M., M.L. Ostilie, H. Hoogerbrugge and K. Bolckmans (2005). Biological control of western flower thrips on sweet pepper using the predatory mites, Amblyseiuscucumerism Iphiseiusdegenerans, Aandersoni and $A$. swirskii. IOBC/WPRS Bulletin 28(1): 283-286.

Wilkinson, J. D. and M. Ignoffo (1975). Contact toxicity of some chemical and biological pesticides to several insect parasitoids and predators. Entomology ph.20:113-120.

Winner, D., D. Hoffmann and P. Schausberger (2008). Prey suitability of western flower thrips, Frankliniellaoccidntalis and onion thrips, Thripstabaci for predatory mite, Amblyseiusswirskii. Biocontrol Sci. Tech. 18(6): 541-550.

Yang, N.W., A.L. Li, F.H. Wan, W.X. Liu, and D. Johnsom (2010). Effects of essential oils on immature and adult sweet potato whitefly, Bemisiatabaci biotype B. Crop Prot. ; 29:1200-1207.

Zehnder, G., J. Kloepper, S. Tuzun, C. Yao, G. Wei, O. Chambliss and R. Shelby (1997). Insect feeding on cucumber mediated by rhizobacteriainduced plant resistance. Entomologia Experimentalis et Applicata. 83(1): 81-85.

Zhang, S., M. Reddy and J.W. Kloepper (2002). Development of assays for assessing induced systemic resistance by plant growth-promoting rhizobacteria against blue mold of tobacco. Biological Control. 23(1): 7986. 
دور إحدى عزلات بكتريا Bacillus thuringiensis كوسيلة مكافحة بيولوجية للاببابة البيضاء Bemisiatabaci وأثرها الجانبى علي المفترس Euseiusscutalis

إيمان إبراهيم إمام (1)، محمد عادل نوار (2)

(1) وحدة الحشرات الاقتصاديه - قسم وقاية النبات- مركز بحوث الصحراء إنباء (2) وحدة الآقات الحيوانيه- قسم وقاية النبات - مركز بحوث الصحراء

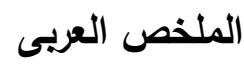

أجريت هذه الاراسة بغرض تقييم سميه عزله من البكتيريا الممرضة للحشرات باسيليس ثيرونجينسيس عليحوريات

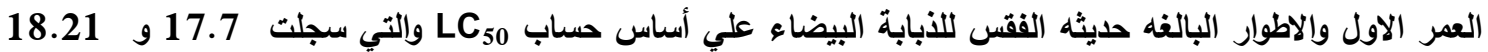

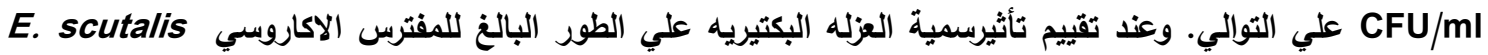

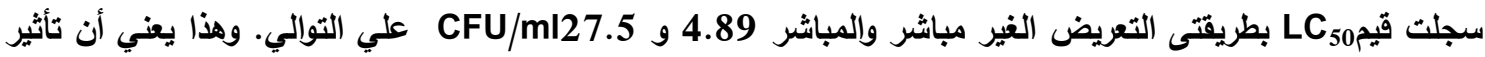
المبيد علي المفترس في الطريقة الغير مباشرة يكون أكثر سمية عن المعاملة بالطريقة المباشرة.

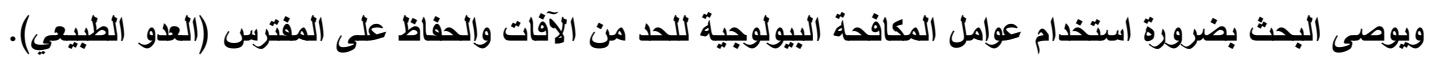


$\underline{\text { Role of bacillus thuringiensis isolate as biological control agent against ............. }}$ 